\title{
Cationic Micronutrient Status of Some Soils under Different Cropping System of Kishtwar District (J\&K), India
}

\author{
A. P. Rai ${ }^{1 *}$, Phuntsog Tundup ${ }^{2}$, A. K. Mondal ${ }^{1}$, Vijay Kumar ${ }^{3}$, A. Samanta ${ }^{4}$, \\ Manoj Kumar ${ }^{5}$, Rohit Kumar Arora ${ }^{6}$ and M. C. Dwivedi ${ }^{7}$
}

${ }^{1}$ Division of Soil Science and Agriculture Chemistry, FoA, Chatha, Sher-e-Kashmir University of Agricultural Sciences and Technology, Jammu -180009(J\&K), India

${ }^{2}$ KVK, Leh, SKUAST-Kashmir-194 101, India

${ }^{3}$ Rainfed Research Sub-station for Sub-tropical fruits, Raya, Sher-e-Kashmir University of

Agricultural Sciences and Technology, Jammu -180009(J\&K), India

${ }^{4}$ Water management Research Centre, Chatha, Sher-e-Kashmir University of Agricultural

Sciences and Technology, Jammu-180009(J\&K), India

${ }^{5}$ Regional Horticultural Research Sub-station, Bhaderwah, Sher-e-Kashmir University of Agricultural Sciences and Technology, Jammu -180009(J\&K), India

${ }^{6}$ Directorate of Research, Administrative Building Main Campus, Chatha, Sher-e-Kashmir University of Agricultural Sciences and Technology, Jammu-180009(J\&K), India

${ }^{7}$ Research Farm, Chatha, Sher-e-Kashmir University of Agricultural Sciences and Technology, Jammu -180009(J\&K), India

*Corresponding author

\begin{tabular}{|l|}
\hline K e y w o r d s \\
$\begin{array}{l}\text { Soil properties, } \\
\text { micronutrient, } \\
\text { cropping system, } \\
\text { correlation }\end{array}$ \\
\hline Article Info \\
\hline $\begin{array}{l}\text { Accepted: } \\
\text { 30 December } 2017 \\
\text { Available Online: } \\
\text { 10 January } 2018\end{array}$ \\
\hline
\end{tabular}

Keywords

Soil properties, micronutrient, cropping system,

Accepted:

Available Online:

2018

\section{A B S T R A C T}

A study of the cationic micronutrient status of soils of district Kishtwar was made at five different cropping systems (Maize - oats, Rice - mustard, Moong -Berseem, Agri - horti system and Vegetable). The DTPA-extractable micronutrient cations and their relationship with different soil properties were studied in different cropping system of Kishtwar district $(\mathrm{J} \& \mathrm{~K})$. Soil samples were collected at a depth of $0-15 \mathrm{~cm}$ and analyzed for DTPA- extractable iron, copper, zinc, manganese. The DTPA extractable Iron, Copper, Zinc and Manganese ranged from 5.37-23.36, 0.59-4.38, 0.74-2.08 and 4.59-21.08 $\mathrm{mg} \mathrm{kg}^{-1}$. Soil DTPA-extractable micro-nutrients, $\mathrm{Zn}, \mathrm{Cu}, \mathrm{Mn}$, and $\mathrm{Fe}$ ranged from 1.24 to $5.55,1.20$ to $2.97,13.26$ to 47.56 and 7.17 to $17.17 \mathrm{mg} \mathrm{kg}^{-1}$ (mean value of $2.34,2.10,22.35$ and $10.65 \mathrm{mg} \mathrm{kg}^{-1}$ ), respectively. Correlation between the soil physico-chemical properties and nutrient concentrations showed a significant and positive relationship between CEC and clay content $(\mathrm{r}=0.827 * *)$. Soil $\mathrm{pH}$ of the surface layer had a significant and negative correlation with $\mathrm{Cu}, \mathrm{Mn}$ and $\mathrm{Fe}$ $\left(\mathrm{r}=-0.281^{* *}, \mathrm{r}=-0.455^{* *}, \mathrm{r}=-0.367 * *\right)$. Soil organic carbon showed a significant positive relationship with the available nitrogen, and copper $\left(r=0.846^{* *}, r=0.256^{*}\right)$. 


\section{Introduction}

Role of cationic micronutrient in balanced plant nutrient is well established. There are important for maintaining soil health and also increasing productivity of crops. These are needed in very small amount (Rattan et al., 2009). The required micronutrients by the plants zinc, copper, manganese and iron $(\mathrm{Zn}$, $\mathrm{Cu}, \mathrm{Mn}$ and $\mathrm{Fe}$ ). Although these nutrients are present relatively in small amount in nearly all the soils, yet their availability presents a problem in many soils. The nature and amount of various forms of micronutrients are affected by the factors like soil moisture, soil temperature, $\mathrm{pH}$, organic matter content, etc. It was, therefore, reasonable to expect that concentration of different forms of these micronutrients in soils of different physicochemical properties is likely to vary (Sharma and Chaudhary 2007). Thus, knowledge of status of micronutrient and their interrelationship with soil characteristic will be helpful in understanding the inherent capacity of soil to supply these nutrients to plant. Beside soil characteristics, land use pattern also plays a vital role in governing the nutrient dynamics and fertility of soils (Venkatesh et al., 2003). Major crops of the district Kishtwar are Maize, Paddy, wheat and barley, rajmash, vegetables, and horticulture. The average productivity of major crops were below national average, may be because of the landscape of these hilly terrain of the district and complex nature of the soil; fertility status and available cropping pattern.

The relatively minor problem of soil micronutrient deficiency at the beginning of the green revolution three decades ago was a factor to reckon with in present times in sustaining the productivity of crop. Proper management of the different cropping system was a key to minimize crop yield reduction induced by micronutrient deficiency. The micronutrient content of soils are of limited value to plant growth and responses to their application. To match the levels of micronutrient was soil with plant requirement; their available contents in soils were to be determined. Like total contents, the available micronutrient status of soils is also highly variable. Soil properties exercise a considerable influence on the availability of micronutrients. Since the state of Jammu and Kashmir has also got on an ambitious agricultural development programme with a great stress on intensive farming, it is likely that the farmers of this state may face the problem of macro as well as micronutrient deficiencies in their soils. This has caused concern to those who are associated with the crop in Kishtwar in one way or the other. Among other things, low productivity, may be attributed to low fertility of these soils, both in respect of micronutrients. This was authenticated by the fact that Karewas have been reported deficient in $\mathrm{Zn}$ Tundup, et al., (2015). Since no systematic information was yet available on status of micronutrient in different cropping system soil of Kishtwar District. The present work was conducted to assess the status of micronutrient in different cropping system soil of Kishtwar District. There was a general lack of awareness among farmers on micronutrient deficiency problem.

\section{Materials and Methods}

The present investigation was undertaken in Kishtwar district of J\&K State. These study area has severely to moderately eroded soils located between at $32^{\circ} 53^{\prime}$ and $34021^{\prime} \mathrm{N}$ latitude and $75^{\circ} 1^{\prime}$ and $76^{\circ} 47^{\prime}$ E longitude of 1600 to $1800 \mathrm{~m}$ above MSL. Five different cropping system (Maize -oats, Rice mustard, Moong -Berseem, Agri - horti system and Vegetable) of Kishtwar were selected for random soil sampling to study the as well as micronutrients status. Seventy five surface $(0-15 \mathrm{~cm})$ soil sample, representing five different cropping system i.e. 15 each 
were collected from Kishtwar district of J\&K. The processed soil samples are analyzed for physico-chemical properties using standard procedures (Jackson, 1973). The available Zn, $\mathrm{Cu}, \mathrm{Fe}, \mathrm{Mn}$ in soil samples were extracted with solution consisting of $0.005 \mathrm{M}$ DTPA, $0.01 \mathrm{M} \mathrm{CaCl}_{2}$ and $0.1 \mathrm{M}$ Triethanolamine $(\mathrm{pH}$ 7.3) as per the procedure described by Lindsay and Norvell (1978) for available micronutrient cations. The $\mathrm{Zn}, \mathrm{Cu}, \mathrm{Fe}, \mathrm{Mn}$ in DTPA-extracts were estimated using atomic absorption spectrophotometer Model, Z2300 (Hitachi).

\section{Results and Discussion}

\section{Physico-chemical Characteristics of soils}

The important soil properties of soils of the five different cropping system under study are presented in Table 1. However, the average $\mathrm{pH}$ of Maize -oats, Rice - mustard, Moong Berseem, Agri - horti and Vegetable system soils were $6.51,6.14,7.01,7.11$ and 6.88, respectively which shows that the majority of the soils is acidic to neutral in reaction. The electrical conductivity (EC) of these soils varied from 0.05 to $0.35 \mathrm{dSm}^{-1}$. These values are within the safe limits for the growth of the crop. The organic carbon content of the soils was medium to high. The soil of organic carbon content five different cropping systems ranged from 5.1 to $8.5 \mathrm{~g} \mathrm{~kg}^{-1}$ with the mean value of $6.1,5.9,6.5,7.4$ and $7.1 \mathrm{~g} \mathrm{~kg}^{-1}$. The fertility status of the soil for the quantity of organic carbon content of soils was wide variation. Similar results are reported by Kumar et al., (2010) and Kumar and Sohan (2012).

The clay content of the soils ranged from 26.93 to 34.91 percent which subscribe to same range as reported by Rai, et al., (2017). Cation exchange capacity (CEC) ranged between 10.46 to $16.41\left[\mathrm{cmol}(\mathrm{p}+) \mathrm{kg}^{-1}\right]$ with mean value of $12.51,14.61,13.44,12.54$ and 13.41. These observations are corroborated by
Gupta and Khanna (1994) while studying soils of agricultural research farm of Jammu.

\section{Micronutrient cations}

Zinc: DTPA- extractable zinc content of soils under different cropping system varied from 0.40 to $3.41 \mathrm{mg} \mathrm{kg}^{-1}$ with an average value of $1.21,0.68,1.34,1.94$ and $1.41 \mathrm{mg} \mathrm{kg}^{-1}$ soil under Maize -oats, Rice - mustard, Moong Berseem, Agri - horti system and Vegetable system, respectively (Table 2). The lower cotent of $\mathrm{Zn}$ under Maize -oats and Rice mustard system soil showed that these soils might develop $\mathrm{Zn}$ deficiency in the agronomy practiceses. The high amount of zinc might have resulted with high organic matter content and more weathered soil conditions. Present investigation indicated that 73 per cent of the different cropping system area was sufficient in available zinc considering, $0.6 \mathrm{mg} \mathrm{kg}^{-1}$ as the critical limit as suggested by Lindsay and Norvell (1978). This was supported by the findings of Chattopadhyay et al., (1996) who also found sufficient values of zinc in the hilly soils. Nazif et al., (2006) also reported that micronutrient availability enhanced in soils with organic matter over no organic manure. Organic carbon was found significant positive correlation with $\mathrm{Zn} \quad(\mathrm{r}=0.401 * *)$. The available $\mathrm{Zn}$ in soil has been found negatively correlated with $\mathrm{pH}$ of the soil $(\mathrm{r}=-0.143)$ which is in line with the earlier findings of Vadivelu and Bandyopadhyay (1995). This positive correlation may be due to the formation of organic complexes between organic matter and zinc that protect it from leaching. These results were similar to the findings of Perveen et al., (1993) and Chinchmalatpure et al., (2000). Copper: DTPA-extractable copper ranged from 1.20$4.89 \mathrm{mg} \mathrm{kg}^{-1}$ with an average value of 1.67 , $2.22,1.98,2.44$ and $2.46 \mathrm{mg} \mathrm{kg}^{-1}$ under different cropping system and other agri-horti system soil recorded highest content, whereas, Moong-Berseem system lowest content. 
Table.1 Physico-chemical properties of the soils of different cropping system of Kishtwar district

\begin{tabular}{|c|c|c|c|c|c|}
\hline Cropping System & pH & $\begin{array}{c}\mathrm{EC} \\
\left(\mathrm{dSm}^{-1}\right)\end{array}$ & $\begin{array}{c}\mathrm{OC} \\
\left(\mathrm{g} \mathrm{kg}^{-1}\right)\end{array}$ & $\begin{array}{c}\text { CEC [cmol } \\
\left.\left(\mathbf{p}^{+}\right) \mathrm{kg}^{-1}\right]\end{array}$ & Clay (\%) \\
\hline Maize -oats & $\begin{array}{c}6.26-6.82 \\
(6.51)\end{array}$ & $\begin{array}{c}0.16-0.24 \\
(0.19)\end{array}$ & $\begin{array}{c}5.8-6.8 \\
(6.1)\end{array}$ & $\begin{array}{c}12.25-14.41 \\
(12.51)\end{array}$ & $\begin{array}{c}29.34-33.45 \\
(30.41)\end{array}$ \\
\hline Rice & $\begin{array}{c}5.93-6.48 \\
(6.14)\end{array}$ & $\begin{array}{c}0.17-0.35 \\
(0.21)\end{array}$ & $\begin{array}{c}5.4-6.9 \\
(5.9)\end{array}$ & $\begin{array}{c}13.51-16.32 \\
(14.61)\end{array}$ & $\begin{array}{c}30.62-34.51 \\
(32.15)\end{array}$ \\
\hline Moon & $\begin{array}{c}6.30-7.10 \\
(7.01)\end{array}$ & $\begin{array}{c}0.05-0.18 \\
(0.11)\end{array}$ & $\begin{array}{c}5.1-7.1 \\
(6.5)\end{array}$ & $\begin{array}{c}14.70-16.41 \\
(13.44)\end{array}$ & $\begin{array}{c}27.93-31.45 \\
(29.45)\end{array}$ \\
\hline Agri - & $\begin{array}{c}5.29-7.31 \\
(7.11)\end{array}$ & $\begin{array}{c}0.16-0.25 \\
(0.17)\end{array}$ & $\begin{array}{c}6.9-8.5 \\
(7.4)\end{array}$ & $\begin{array}{r}11.01- \\
\quad(12 .\end{array}$ & $\begin{array}{c}28.65-35.45 \\
(33.65)\end{array}$ \\
\hline Vege & $\begin{array}{c}6.14-7.28 \\
(6.88)\end{array}$ & $\begin{array}{c}0.02-0.25 \\
(0.09)\end{array}$ & $\begin{array}{c}6.3-7.8 \\
(7.1)\end{array}$ & $\begin{array}{c}10.46-15.61 \\
(13.41)\end{array}$ & $\begin{array}{c}26.01-32.61 \\
(30.84)\end{array}$ \\
\hline
\end{tabular}

Table.2 Range and mean of DTPA-extractable micronutrients in soils under different cropping system of Kishtwar district

\begin{tabular}{|l|}
\hline \multicolumn{1}{|c|}{ Village } \\
\hline Maize -oats \\
\hline Rice -mustard \\
\hline Moong-Berseem \\
\hline Agri-horti system \\
\hline Vegetable
\end{tabular}

\begin{tabular}{|c|c|c|c|}
\hline \multicolumn{5}{|c|}{ Micro nutrients $\left(\mathrm{mg} \mathrm{kg}^{-1}\right)$} & Fe \\
\hline $\mathbf{Z n}$ & $\mathbf{C u}$ & $\mathbf{M n}$ & $17.17-19.45$ \\
$0.40-2.02$ & $1.47-2.15$ & $23.41-31.23$ & $(18.41)$ \\
$(1.21)$ & $(1.67)$ & $(26.51)$ & $14.25-16.41$ \\
$0.51-1.45$ & $2.12-3.45$ & $21.14-37.56$ & $(15.34)$ \\
$(0.68)$ & $(2.22)$ & $(29.41)$ & $11.02-21.03$ \\
$1.24-2.14$ & $1.44-2.41$ & $11.23-24.23$ & $(16.348)$ \\
$(1.34)$ & $(1.98)$ & $(19.41)$ & $19.45-23.14$ \\
$1.21-3.41$ & $1.20-4.89$ & $16.45-26.18$ & $(21.35)$ \\
$(1.94)$ & $(2.44)$ & $(20.54)$ & $9.45-23.54$ \\
\hline $0.91-2.14$ & $2.40-3.16$ & $14.51-24.60$ & $(16.54)$ \\
\hline
\end{tabular}

Table.3 Correlation between soil properties and micronutrients

*Significant at the 5\% level.

\begin{tabular}{|c|}
\hline Soil properties \\
\hline pH \\
\hline EC \\
\hline OC \\
\hline CEC \\
\hline Clay \\
\hline
\end{tabular}

\begin{tabular}{|l|l|l|l|}
\hline \multicolumn{4}{|c|}{ Macronutrients } \\
\hline $\mathrm{Zn}$ & $\mathrm{Cu}$ & $\mathrm{Mn}$ & $\mathrm{Fe}$ \\
\hline-0.143 & $-0.295^{*}$ & $-0.415^{* *}$ & $-0.397 * *$ \\
\hline 0.168 & 0.061 & -0.039 & 0.154 \\
\hline $0.401 * *$ & $0.266^{*}$ & 0.121 & 0.127 \\
\hline-0.131 & -0.031 & $0.284 *$ & 0.083 \\
\hline 0.031 & $-0.249 * *$ & $0.395 * *$ & 0.114 \\
\hline
\end{tabular}

** Significant at the $1 \%$ level. 
No deficiency was observed as the values are above the critical limit of $0.2 \mathrm{mg} \mathrm{kg}^{-1}$, (Lindsay and Norvell, 1978). This was in agreement with the study of Chattopadhyay et al., (1996).Soils with good organic matter content have high micronutrient availability due to chelating action of organic compounds released during decomposition and prevention of cations from fixation, precipitation, oxidation and leaching (Babu et al., 2007). Copper and soil $\mathrm{pH}$ was negatively and significantly correlated with $\mathrm{r}$ value of $-0.295^{*}$ (Table 3) indicating that a decline in $\mathrm{pH}$ leads to significant increase in copper availability. Similar correlation coefficients were also worked out by Bhandari and Randhawa (1985). Further data indicated that $\mathrm{Cu}$ was positively correlated with soil organic carbon $\left(\mathrm{r}=0.266^{*}\right)$. Similar results were reported by Khalifa et al., (1996) and Rajakumar et al., (1996) who also reported a positive correlation between copper and organic matter.

Manganese: DTPA-Mn study varied from $11.32-31.23 \mathrm{mg} \mathrm{kg}^{-1}$ in five different cropping system with mean value of $26.51,29.41$, $19.41,20.54$ and $18.64 \mathrm{mg} \mathrm{kg}^{-1}$ respectively. Manganese content of the soils varied widely and was higher under Rice - mustard cropping than other cropping system. Considering $1.0 \mathrm{mg} \mathrm{kg}^{-1}$ as the critical limit for $\mathrm{Mn}$ deficiency (Lindsay and Norvell 1978), cent percent of the soils have sufficient available $\mathrm{Mn}$ to sustain different cropping system. Soils with good organic matter content have high micronutrient availability due to chelating action of organic compounds released during decomposition of these manures and prevention of cations from fixation, precipitation, oxidation and leaching (Babu et al., 2007).Mn and soil $\mathrm{pH}$ was negatively and significantly correlated with $r$ value of $-0.415^{*}$ (Table 3). It was showed significant positive correlation with CEC and clay content $\left(\mathrm{r}=0.284^{*}\right.$ and $\left.0.395^{* *}\right)$. The significant relationships between clay and $\mathrm{Mn}$ signify the importance of clay in the availability of this micronutrient. The result was positively significant and in conformity with Oyinlola et al., (2010) and Tundup, et al., (2015).

Iron: The data in table 2, indicated that available iron $(\mathrm{Fe})$ content of the soil under five different cropping system varied from $9.45-23.54 \mathrm{mg} \mathrm{kg}^{-1}$ with mean value of $18.41,15.34,16.34,21.35$ and $16.54 \mathrm{mg} \mathrm{kg}$ ${ }^{1}$ respectively. Available $\mathrm{Fe}$ was sufficient in the soils assuming $4.5 \mathrm{mg} \mathrm{kg}^{-1}$ as a critical limit as suggested by Lindsay and Norvell (1978). These findings were in conformity with that of Nazif et al., (2006) and Kirmani et al., (2011). This might be attributed to synergistic relationship of physico-chemical characteristics and micronutrient in soil. Soils with good organic matter content have high micronutrient availability due to chelating action of organic compounds released during decomposition of these manures and prevention of cations from fixation, precipitation, oxidation and leaching (Babu et al., 2007). There was a negative and significant relationship between DTPA-Fe and $\mathrm{pH}\left(\mathrm{r}=-0.397^{* * *}\right)$. It was observed that availability of $\mathrm{Fe}$ like other micronutrients $(\mathrm{Cu}$ and $\mathrm{Mn})$ decreases with the increase in soil $\mathrm{pH}$. These results are supported by the earlier findings of Rajakumar et al., (1996) and Tundup, et al., (2015).

Thus it may be concluded that the five different cropping system (Maize -oats, Rice - mustard, Moong -Berseem, Agri - horti and Vegetable) areas of Kishtwar district of Jammu province were sufficient in DTPAextractable $\mathrm{Zn}, \mathrm{Cu}, \mathrm{Mn}$ and $\mathrm{Fe}$ contents. The information regarding the micronutrient status of the soils of Kishtwar district in present investigation may be helpful in the formulation of integrated nutrient management schedule for the better 
cultivation practices and sustainance for long term of soil health.

\section{References}

Babu, M.V.S., Reddy, M.C., Subramanyam, A. and Balaguravaih, D. 2007. Effect of integrated use of organic and inorganic fertilizers on soil properties and yield of sugarcane. Journal of the Indian Society of Soil Science, 55(2): 161-166.

Bhandari, A. R. and Randhawa, N. S. 1985. Distribution of available micronutrients in soils of apple orchards of Himachal Pradesh. Journal of the Indian Society of Soil Science, 33: 171-173.

Chattopadhyay, T. Sahoo, A.K. Singh, R.S. and Shyampura, R.L. 1996. Available micronutrient status in the soils of vindhyan scarp lands of Rajasthan in relation to soil characteristics. Journal of the Indian Society of Soil Science, 44(4): 678-681.

Chinchmalatpure, A. R., Brij Lal, Challa, O., Sehgal, J. 2000. Available micronutrient status of soils on different parent materials and landforms in a microwatershed of Wunna catchment near Nagpur (Maharashtra). Agropedology, 10(1): 53-58.

Gupta, J. P. and Khanna, Y. P. 1994. Nutrient status of the soil of agricultural research farms of Jammu region ( $\mathrm{J} \& \mathrm{~K})$. Research and Development Reporter, 11(1-2):6770

Jackson, M. L. 1973. Soil chemical analysis: Advanced course. The Author. Madison, Wisconsin, USA.

Khalifa, E. M., El-Desoky, M. A., Gameh, M. A. and Faragallah, M. E. 1996. Status of some micronutrients and their relations to mineral composition of the Nile valley desert interference zone soils, East of Assiut city. Assiut Journal of Agricultural Sciences, 27(3): 107-127.

Kirmani, N.A., Sofi, J.A., Bhat, M.A.,
Bangroo, S.A. and Bhat, S.A. 2011. Soil Micronutrient Status of District Budgam. Research Journal of Agricultural Sciences, 2(1): 30-32.

Kumar, V. and Sohan, P. 2012. Status of Major Nutrients in soils of Raya orchard under rainfed condition. An Asian Journal of Soil Science 7(2):402-403.

Kumar, V., Singh, G.R., Kumar, A. and Pathinia, K. 2010. Status of Major Nutrients in soils of Haridwar District. Environment and Ecology 28(2): 759761.

Lindsay, W. L. and Norvell, W. A. 1978. Development of a DTPA soil test for zinc, iron, manganese, and copper. Journal of the American Society of Soil Science, 42: 421-428.

Nazif, W., Perveen, S. and Saleem, I. 2006. Status of micronutrients in soils of district Bhimber (Azad Jammu and Kashmir). Journal of Agricultural and Biological Science, 1(2): 35-40

Oyinlola, E.Y. and Chude, V.O. 2010. Status of available micronutrients of the basement complex rock-derived alfisols in northern Nigeria savanna. Tropical and Subtropical Agroecosystems, 12: 229-237.

Perveen, S., Tariq, M., Farmanuallah, Khattak, T.K. and Hamid, A. 1993. Study of some important sites of N.W.F.P., Pakistan. Sarhad Journal of Agriculture, 9(5): 467-473.

Rai, A.P., Mondal, A.K., Rai, P.K., Gupta R. and Kumar V. 2017. Micronutrient Status of Rice Growing Soils in Samba District of J\&K (Edited by Sanjay Arora Suraj Bhan) Sustainable Farming and Soil Health Management, Soil Conservation Society of India, New Delhi. Chapter 8 Pp. 66-70.

Rajakumar, G.R., Patil, C.V., Prakash, S.S., Yeledhalli, N.A. and Math, K.K. 1996. Micronutrient distribution in paddy soils in relation to parent material and soil 
properties. Karnataka Journal of Agricultural Sciences, 9(2): 231-235.

Rattan, R. K., Patel, K. P., Manjaiah, K. M. and Datta, S. P. 2009. Micronutrient in soil, plant animal and human health. Journal of the Indian Society of Soil Science 57, 546-558

Sharma, J. C., and Chaudhary, S. K. 2007.Vertical distribution of micronutrient cations in relation to soil characteristics in lower Shiwaliks of Solan district in North-West Himalayas. Journal of the Indian Society of Soil Science 44(4): 746-752.

Tundup, P., Rai, A. P., Mondal A. K., Kumar, V. and Wali P. 2015. Nutrient status of saffron growing soils of Kishtwar district $(\mathrm{J} \& \mathrm{~K})$. Journal of the Indian Society of Soil Science, 63(4): 394-399.

Vadivelu, S. and Bandyopadhyay, A.K. 1995. Distribution of DTPA extractable Fe, $\mathrm{Mn}, \mathrm{Cu}$ and $\mathrm{Zn}$ in the soils of Minicoy Island, Lakshadweep. Journal of the Indian Society of Soil Science, 43(1): 133-134.

Venkatesh, M. S., S. Aetia, R. K., Sharma, P. K., Khurana M. P., S. and Kang, G. S. 2003. Status of micronutrient cation under various land use system of Meghalaya. Journal of the Indian Society of Soil Science, 51: 60-64.

\section{How to cite this article:}

Rai A. P., Phuntsog Tundup, A. K. Mondal, Vijay Kumar, A. Samanta, Manoj Kumar, Rohit Kumar Arora and Dwivedi M. C. 2018. Cationic Micronutrient Status of Some Soils under Different Cropping System of Kishtwar District (J\&K), India. Int.J.Curr.Microbiol.App.Sci. 7(01): 3596-3602. doi: https://doi.org/10.20546/ijcmas.2018.701.422 